\title{
Sevgi Ayakları: “Uysal Özneler” Üzerinden Bir 12 Eylül Okuması
}

\section{Sevgi Ayaklart: A Reading of the 1980 Coup through "Docile Subjects"}

Ayşe Sancak Deniz ${ }^{1}$ (D)

'Doktora Öğrencisi, İstanbul Üniversitesi, Sosyal Bilimler Enstitüsü, Tiyatro Eleştirmenliği ve Dramaturji Anabilim Dalı, İstanbul, Türkiye

\section{ORCID: A.S.D. 0000-0002-1153-1152}

\section{Sorumlu yazar/Corresponding author: Ayşe Sancak Deniz, \\ İstanbul Üniversitesi, Sosyal Bilimler Enstitüsü, Tiyatro Eleştirmenliği ve Dramaturji Anabilim Dalı, İstanbul, Türkiye \\ E-posta/E-mail: aysancak@hotmail.com}

Başvuru/Submitted: 30.10 .2020 Revizyon Talebi/Revision Requested: 18.01.2021

Son Revizyon/Last Revision Received: 18.01.2021

Kabul/Accepted: 30.01 .2021

\section{Atıf/Citation:}

Sancak, Ayșe. "Sevgi Ayakları: “Uysal Özneler” Üzerinden Bir 12 Eylül Okuması" Tiyatro Eleştirmenliği ve Dramaturji Bölümü Dergisi 32, (2021): 125-144

https://doi.org/10.26650/jtcd.818543

\section{ÖZ}

Bu çalışma Bilgi Sosyologu olan Peter L. Berger ve Thomas Luckmann'ın gerçekliğin sosyal inşası kuramından yola çıkarak Memet Baydur'un 1992 yılında yazdığı Sevgi Ayakları adlı oyununu egemen güçlerin hegemonik olduğu toplumsal gerçekliği içselleştiren bireylerin kendi ürettikleri gerçekliğe yabancılaşması bağlamında incelemeyi amaçlamaktadır. Bu anlamda 12 Eylül 1980 Askeri Darbesinin baskı ve şiddetle kurguladığı siyasal, ekonomik ve kültürel gerçekliklerini içselleştiren bireylerinin kendilerine ve topluma yabancılaşması, toplumsal gerçeklik üzerinde hegemonik olan egemen gücün kolektif belleği hedef alarak gerçeklik zeminini bozması yönünden ele alınacaktır. Ayrıca 12 Eylül'ün ideolojik ve baskı aygıtları aracılığıyla uysal özne inşa etme sürecinde bireyin öznel gerçekliklerini ve normlarını değiştirmesi, Michel Foucault'un disiplinci iktidar kavramılla birlikte değerlendirilecektir.

Anahtar Kelimeler: 12 Eylül, Toplumsal Gerçeklik, Uysal Özne, Yabancılaşma, Kolektif Bellek

\section{ABSTRACT}

This study analyses Sevgi Ayakları, a 1992 play written by Memet Baydur, within the framework of individual alienation and the internalization of social reality prevailed upon by dominant powers. The analysis also draws from sociologists Peter L. Berger and Thomas Luckmann's theory of social construction of reality. In this regard, the fact that individuals, who have internalized cultural, economic and political realities constructed by the September 12th, 1980 coup d'état through oppression and violence, have become self-alienated from the society is dealt with by considering the breakdown of reality by the dominant powers reigning over social reality, aiming at collective memory. Furthermore, the 1980 coup's altering individuals' subjective realities and norms while creating docile subjects through ideological and oppression apparatus is evaluated using Michel Foucault's concept of "disciplinary power".

Keywords: September 12, Social Reality, Docile Subject, Alienation, Collective Memory 


\section{EXTENDED ABSTRACT}

In their theory on the social construction of reality, the sociologists Peter L. Berger and Thomas Luckmann state that objective reality is a man-made product. Through reification, humans have internalized it as a heavenly product that has emerged without their interference. The contradiction of experiencing this world as something other than man-made while being capable of creating it corresponds to the reification of reality or its reflection as alienated. However, the intervention of the dominant power to form or manipulate perceptions of reality by attributing meanings to ideas, notions and actions indicates that social reality has not been constructed or generated by supernatural powers as natural laws are, out of the blue, on their own. On the contrary, it showcases that reality is open to manipulation and fictional because it is a result of the dominant power or view. Thus, the 1980 military coup d'état can be said to be an initiative to create a new social reality that was compatible with the interests of dominant powers, altering the existing reality via the government apparatus of oppression and ideology.

Following the 1980 coup, the social reality was reconstructed per the requirements of neoliberal economic policies, which included consumption, egocentrism, image, docility and other identities appropriated by the dominant ideology. Masses that produced social practice, such as foundations, organisations, associations, unions, political parties, higher education institutions, and media outlets, were prevented from congregating through depoliticisation and the way for the establishment and adoption of dominant ideology was laid open. The individual producing the former regime's discourse became insignificant, neutralized, marginalized, and ostracized.

In Michel Foucault's “disciplinary power," the individual disciplines themselves through a self-evaluation that employs the norms of the power. In disciplinary power, individuals turn into the desired docile subjects by learning and internalizing the hierarchy, discourses of truth, norms, differences, and comparisons that are produced for them. Individuals internalize what is good, bad, true, wrong, desirable, and undesirable; who is persona grata; and who is a traitor for the regime via the control mechanisms imprinted in them through institutions such as prisons, courts and schools. This type of power is closely related to the 1980 coup that turned organizations, masses and individuals held responsible for chaos, violence, instability, and defiance against reigning power into docile and apolitical subjects. The optimal subject internalizes the realities of the new order, with their conscience monitored through the government apparatus of oppression and ideology.

Memet Baydur began writing plays in the early 1980s. He produced plays that showcased the 1980 regime, which masked the interests of dominant powers and built a new social reality to construct an identity compatible with those interests. As a witness to the 1980 military intervention, Baydur aimed to demonstrate physical and mental devastation of a society that lost its grounding in reality, by addressing the predicaments, strangeness, lack of communication, and 
alienation of the individual whom the 1980 coup not only alienated, silenced, and suppressed but also diminished and made unworthy. In Sevgi Ayakları, Baydur scrutinizes the new world order as exemplified by an urban middle class consumed by egocentrism, materialism, and greed. He displays the contradictions of the disciplined individual, questions their cliché values and exposes their highbrow standing as banal and insensitive, ultimately criticizing the social reality the 1980 coup regime strived to construct. This study aims to demonstrate that the 1980 coup, having imprinted the disciplinary power in the individual and disrupted their perception of reality, is a project of constructing an identity that is compatible with the interests of the reigning powers over society through a play dealing with post-1980 individuals who are criticized for their lack of identity and memory. 


\section{Giriş}

Peter L. Berger ve Thomas Luckmann gerçekliğin sosyal inşası kuramında "sosyal düzenin insani bir üretim olduğu, onun insanın dışsallaşması esnasında üretildiği ve insanın ürettiği bu gerçekliği kendisinin dışında bir şey gibi görüp içselleştirdiğini"’1 savunmuştur. Onlara göre, sosyal düzen şeylerin doğasının bir parçası değildir, insan faaliyetinin ürünüdür. Yani doğa yasalarıyla üretilmeyen gerçekliğin, doğa yasası ya da insan-üstü üretim olarak görülmesi "gerçekliğin şeyleşmesiyle"2 ilgilidir. İnsanın bu dünyayı üretmeye muktedir olup, sonradan onu insani bir üründen başka bir şey olarak tecrübe etmesindeki çelişki de gerçekliğin bilince şeyleşerek veya yabancılaşmış halde yansımasına tekabül eder. Fakat topluma egemen olan gücün, gerçeklik algılamalarını yapılandırmaya ya da düşüncelere, olgulara, eylemlere anlam yükleyerek algılanış biçimlerini değiştirmeye yönelik müdahaleleri, toplumsal gerçekliğin doğa yasası gibi kendiliğinden veya doğa-üstü güçler tarafından oluşturulmadığını, bilakis bu gerçekliğin egemen güç ya da ideolojilerin etkisiyle manipülasyona açık ve kurgu olduğunu gösterir. Berger ve Luckmann'ın, “belirli bir gerçeklik tanımı somut bir iktidar çıkarına eklemlenmeye başladığında bunu ideoloji olarak adlandırmak mümkün olur"3 şeklindeki ifadesi de ideolojinin egemen gücün çıkarına uygun anlamı üreten yapı olduğuna işaret eder.

Bu anlamda 12 Eylül 1980 Askeri Darbesi'nin devletin baskı ve ideolojik aygıtları aracılığıyla var olan toplumsal gerçekliği değiştirerek, egemen güçlerin çıkarlarına uygun yeni bir toplumsal gerçeklik ve kimlik inşa etme girişimi olduğu söylenebilir. Murat Belge, buna neden ihtiyaç duyulduğunu şu şekilde açıklamaktadır:

12 Eylül temelde yurttaşa devletini hatırlatmak, bu yoldan haddini bildirmek girişimiydi. Yurttaşlar sınıf, mezhep, inanç ve etnik köken farklarının fazlasıyla etkisine girmişler, Türkiye Cumhuriyeti devletinin ideal uyruklarına yaklşan renksiz, kokusuz, köşesiz, uysal yaratıklar olmaktan çıkma belirtileri göstermeye başlamışlardı. Bu duruma derhal son vermek gerekiyordu. ${ }^{4}$

Devletin toplumsal gerçeklik üzerinde hegemonya kuramadığı 12 Eylül öncesinde birey, dinamik, örgütlü, sorgulayan, üzerinde denetim kurulamayan ve son derece politik olan bir özneye dönüşmüştür. 12 Eylül'ün görevi bu bireyi devlete itaat eden özneye dönüştürmektir. Bu doğrultuda 1982 Anayasası ile özellikle bireyin temel hak ve özgürlüklerine kısıtlama getirilmiş, örgütlerde, derneklerde, kurumlarda, vakıflarda, toplantılarda, gösterilerde, yürüyüşlerde, grevlerde bir araya gelmesi yasaklanmış, siyasi partilerle temsil bağı koparılmıştır. Mevcut düzen ise neo-liberal politikalara göre, tüketim olgusuna göre, benmerkezciliğe göre, imaja

1 Peter L. Berger, Thomas Luckmann, Gerçekliğin Sosyal İnşast : Bir Bilgi Sosyolojisi Incelemesi, çev. Vefa Saygın Öğütle (İstanbul: Paradigma Yayınları, 2008), 79.

2 A.g.e., 131.

3 A.g.e., 178.

4 Murat Belge, 12 Yıl Sonra 12 Eylül (İstanbul: Birikim Yayınları, 2000), 43. 
göre, uysal öznelere göre ve egemen ideolojinin diline tercüme ederek içinde erittiği öteki kimliklere göre yeniden kurgulanmıştır.

Dönemin tiyatro yazınına baktığımızda ise 1980 öncesinin kitleleri peşinden sürükleyecek olaylarının ve kişilerinin gözden düştüğü, toplumsal gerçeklikten uzak, gündelik gerçekliklerin aktarılamadığı, soyut, yabancılaşmış, bireyselleşmiş, yalnızlaşmış, bencilleşmiş öznelerin hikâyelerini konu edinerek bir içe kapanma dönemi yaşandığ 1 ve bu eleştirilerin dayanağı olan 12 Eylül darbesinin uyguladığı baskı, sansür ve şiddetin toplumsal olanı her şeyiyle anlatmaya imkân tanımadığı dolayısıyla toplumsal gerçekliğin anlatılamadığı ve bundan dolayı da farklı anlatım yollarına başvurulduğu yönünde yapılmış genel bir tespit vardır. Bunlardan birisi olan Müzeyyen Buttanrı dönemin tiyatrosuyla ilgili şu değerlendirmeyi yapmıştır:

1980’li 1990’ll yıllarda tiyatromuzda durgunluk görülür. Sansürlü yıllardır. Müzikli hafif oyunlar sahneye konur. Seyircinin tercihi de kendisini güldürecek oyunlardır. Bu yıllarda yeni oyun yazarlarımız pek yetişmez. Siyasi ortam, yasaklar, pek çok oyunun yazılmasına, oynanmasına, tartışılmasına firsat vermemiştir....

$\mathrm{Bu}$ değerlendirmeden de anlaşılacağı üzere depolitizasyon koşullarında 12 Eylül'ün kurguladığ 1 gerçekleri doğrudan oyunlara yansıtmak zordur. Yazarlar darbe iktidarının hışmına uğramamak için ya basit güldürülerle gününü kurtarmış ya da bu gerçekleri dil oyunlarına, postmodern anlatı tekniklerine, göndermelere, soyutlamalara başvurarak dile getirmek zorunda kalmıştır.

Yazarlık hayatına 80'li yıllarda başlayan Memet Baydur, yeni düzen eleştirisini dolaylı yollara başvurarak yapan yazarlarımızdandır. 12 Eylül'e tanıklık etmiş bir yazar olarak 12 Eylül'ün susturduğu, sindirdiği, değersizleştirdiği, sıradanlaştırdığ 1 ve yalnızlaştırdığı bireyinin açmazlarını, tuhaflıklarını, iletişimsizliğini, yabancılaşmasını ele alarak gerçeklik zeminini kaybeden toplumun zihinsel ve bedensel tahribatını göstermeye çalışmıştır. Ayşegül Yüksel, Baydur'un oyunlarında ele aldığı bireyleri, “12 Eylül'ün, toplumu sindirme, eylemsizleştirme yolunda kazandı̆̆ı psikolojik başarının ürünleri” ${ }^{\circ}$ olarak tanımlamıştır. Baydur Sevgi Ayakları adlı oyununda, tüketim koşullarına ve benmerkezciliğe göre dizayn edilmiş düzende kentli, orta sınıf kimliklerini mercek altına alarak, disipline edilmiş bireyin çelişkilerini göstererek, kalıplaşmış değer yargılarını sorgulayarak, duyarsızlaşmış ve sıradanlaşmış aydın konumunu ifşa ederek 12 Eylül'ün inşa etmeye çalıştığı öznelik konumlarını eleştirmiştir. Bu çalışmanın temel amacı ise, 80 sonrasının kimliksiz ve belleksiz olmakla eleştirilen bireylerini ele alan bu oyun üzerinden, disiplin iktidarını bireyin içine yerleştiren ve gerçeklik algılarını bozan 12 Eylül'ün aslında topluma egemen olan güçlerin çıkarlarına uygun bir kimlik inşa etme projesi olduğunu göstermektir.

5 Müzeyyen Buttanr1, "Cumhuriyet Devri Türk Tiyatrosunda Batı Etkisi”, Turkish Studies, Language and Literature 5/2 (2010), 69.

6 Ayşegül Yüksel, Çağdaş Türk Tiyatrosundan On Yazar (İstanbul: Mitos-Boyut Yayınları, 1997), 134. 


\section{Eve Dönen Yabancılar}

Sevgi Ayakları, iki erkeğin aynı binada çalıştıkları iki kadınla dışarıda bir yemek yiyip geceyi seyahate çıkan bir arkadaşlarının evinde geçirmelerini konu edinen görünürde bir “zamparalık” hikâyesidir. Baydur'un amacı bu görünürde zamparalık hikâyesi üzerinden 12 Eylül’ün muhalifleri nasıl uysallaştırdığını ve yabancılaştırdığını göstermektir. Toplumsal gerçekliğin 12 Eylül öncesi ve sonrasındaki değişimi, bu iki eski devrimcinin kimlikleriyle ve geçmişleriyle yüzleşmelerinde görünür kılınır.

Biri otuz beş diğeri kırk yaşlarında olan iki eski arkadaş Tarık ve Tuğrul, biri yirmi beş diğeri otuz yaşlarında olan Şule ve Ayla ile bir yıl aynı binada çalışmalarına rağmen birbirlerini tanımazlar. Tarık ve Tuğrul, 12 Eylül döneminde muhalif kimliklerinden dolayı hapiste kalmıştır. Belli ki hapisten çıkıp normal hayata döndüklerinde onlar artık birer yabancı olmuştur. Görüp konuşmadıkları, sadece uzaktan baktıkları Ayla ve Şule'yi bir yılın sonunda bir gece birlikte vakit geçirmek için bara davet etmişlerdir. "Dört arkadaş” geceyi seyahate çıkan ve çiçekleri sulamak üzere evinin anahtarını Tarık'a bırakan bir arkadaşının evinde geçirmişlerdir. Tarık ve Tuğrul için, bir gece kızlarla beraber vakit geçirmek, yitirdikleri geçmişleri ve yabancılaştıkları kimlikleri ile yüzleşmekle sonuçlanmıştır. İki erkek ertesi sabah bir gecelik ilişkilerinin, görünürdeki zamparalıklarının "aşka dönüşmesiyle” güne uyanmıştır. Bu "aşk" hikâyesi, 12 Eylül'ün disipline ettiği devrimcilere biçtiği roldür aslında. Nihayetinde zamparalık ya da aşk hikâyesi devrimciler için olağan bir şey değildir. Yeni düzen, politika, dayanışma, emek dışında her şeydir. İki farklı toplumsal gerçekliği anlatmak için ironiye başvuran Baydur'un bize o gece gösterdiği şey, yeni toplumsal gerçekliğin varlığının sol kimliğin ya da muhaliflerin yokluğu üzerine kurulu olduğudur.

Yazar daha ilk diyaloglarda 12 Eylül düzeninin nasıl kimlik istediğine yer vererek çatışma kuracağı zemini yaratır. Darbe öncesi kimlik, darbe sonrası kimlik. Dört arkadaş barda bir şeyler içtikten sonra eve geldiklerinde Şule gittikleri barın gürültüsünden şikâyet eder. Belli ki bar ve içindeki konuşmalar kadınların ilgisini çekmemiş, hatta konuşmalar ona gürültü gibi gelmiştir.

ŞULE- Ne kadar gürültülü̈ydü bu akşam gittiğimiz bar.

TARIK- Pes. Yapmayın n'olur! Biz orayl sessiz sakin buluruz hep.

ŞULE-Siz?

TARIK-Canım mimarlar, sosyal bilimciler, bir iki doktor, bir iki ressam arkadaş üyemiz de var. Caz dinleyelim, sinema, tiyatro, Asya, Avrupa, cinsellik ve spor konuşalım diye açılmış bir lokal orast.

ŞULE-Çok gürültülüydü.

TARIK- Bize sessiz bile geliyor? ${ }^{7}$

7 Memet Baydur, Tiyatro Oyunları Sevgi Ayakları (İstanbul: İletişim Yayınları, 2016), 557. 
Tarık'ın gittikleri yerin lokal olduğunu söylemesi, oraya kimlerin gittiği ve orada ne konuşulduğuna dair sözleri aslında yeni düzenin kurguladığı kurumlara ve kimliklere bakışının bir göstergesidir. Lokal, bar, cafe yeni düzenin mekânlarıdır; doktor, mimar, ressam gibi aydın kesimi temsil eden kişiler de bu mekânların müdavimleridir. Bu kesimden topluma önderlik eden, sorumluluk alan konumlarından vazgeçerek kendi bireysel ilgi alanlarına yönelmesi istenmiştir. Yazarın Tarık'ın sözlerinde olumladığı şeyler aslında başka türlü söyleyip eleştiremediği şeylerdir. 12 Eylül'ün yeni gerçeklik inşa etmek için toplumu cezalandırması ve kolektif belleği silmesi karşısında entelektüeller, düşünme biçimlerini değiştirerek, kendi öznelliklerini keşfederek, bencilleşerek, bireyselleşerek, pasif ve kayıtsız kalarak, tanık olup olmamış gibi yaparak kendi üzerlerine düşen görevi yerine getirememişlerdir. Ki iktidarın istediği budur. Entelektüellerin bu tavırlarının nedeni depolitizasyon koşulları olsa da dönemin tüketim kültürünün, teknolojik gelişmelerinin ve ekonomi politikalarının da bu tavırda etkisi büyüktür. Murat Belge öznelliklerin öne çıktığ 1980 sonrası döneme Batı’nın çoktan bir isim verdiğinden bahseder.

Batı'da içinde bulunduğumuz bu döneme bir ad takıldı bile: "Ben Çă̆l”" (Me Age), olanları açıklamakta yeterli bir ad olduğu söylenebilir. Bireyin kendini hayatın merkezine koyması, kendini en temel ve vazgeçilmez öncül olarak algılamast ve bütün olaylara, bütün tarihi ve toplumsal düzeylere bu noktadan bakması olarak özetleyebiliriz bu yeni eğilimi. ${ }^{8}$

Doktor, mimar, ressam, sosyal bilimci kendini keşfettikçe etrafına duyarsızlaşacak, bulunduğu toplumsal konumu unutacak ve bencilleşecektir. Cinsellik de bu keşif sürecine dâhildir ve bu dönemde gazetelerde, dergilerde, televizyonlarda bol bol cinsel hazların doyurulmasına yönelik yayınlara yer verilmiştir. Eğlence, sanat, spor, sağlık sektörü tek başına olan bireyi yüceltmiş, onu dayanışma duygularından, toplumsal bağlarından kopararak bireyselleşmesine katkı sunmuştur. Tarık'ın ironik anlatımında olduğu gibi bu lokaller daha ziyade "ben"in isteklerine göre düzenlenen, hobi maksatlı, kişisel hazları doyurmaya yönelik konuşmaların yapıldığı yerlerdir ve işlevleri böyle belirlendiği için de bu mekânlar toplumsal gerçekliği iktidarın hegemonyasından kurtaracak siyasetlerin üretileceği yerler değildir. Asya, Avrupa konuşulsun ama yeter ki Türkiye konuşulmasın!

İlerleyen saatlerde "dört arkadaş" eve geldiklerindeki tedirginliği üzerlerinden atmış, kahveler, konyaklar, viskiler içilmiş, Ayla duşunu almış, zaman farklılığından söz edilmiş, şimdilerde moda olan "ot” yemeklerinden bahsedilmiş, ülkede insanların haftada bir banyo yaptığı, çamaşırlarını iki haftada bir değiştirdiği hatta Şule’nin ayak fetişisti olan kocasını boşaması bile anlatılmıştır. Sevda Şener bu konuşmaları ve eylemleri "içteki huzursuzluğu” örtecek "dıştan rahat görünme çabası” olarak değerlendirmiştir. ${ }^{9}$ Hiç de olağan olmayan ama

8 Murat Belge, "Yeni İnsan Yeni Kültür”, Yüzyıl Biterken Cumhuriyet Ansiklopedisi 13 (İstanbul: İletişim Yayınları, 1996), 827.

9 Sevda Şener, Gelişim Sürecinde Türk Tiyatrosu, (İstanbul: Mitos-Boyut Yayınları, 2011), 234. 
olağanmış gibi yapılan bu davranışlar iletişim kurmak için bir dil arandığını gösterir. Bu çabalar asıllarının taklidi gibi duran bu iki erkeğin kim olduğunu öğrenmeye yöneliktir.

Onlar eskinin iki devrimci kimliği şimdininse geçmişine ve kimliğine yabancılaşmış uysal özneleridir. Devrim yapma uğruna çıktıkları yolda 12 Eylül'ün zulmüne maruz kalmaları ve yalnız bırakılmaları karşısında bir ağıt gibidir Tarık'ın anlattıkları.

TARIK- Politik suçlulardık ikimiz de. (Sessizlik) Bize benzeyen insanların yaşama hakkını savunmak için kurduğumuz siyasi ve kültürel örgüt yüzünden, bize benzeyen insanlar tarafindan yargllanip, bize benzeyen idarecilere teslim edildik ve bize benzeyen insanların yanina, hapishaneye konulduk. Gardiyanlar da bize benziyordu, nöbetçiler de, müdürler de ziyaretçiler de... Yöneticilerle, yönetilenlerin... İktidarla muhalefetin... Ezen ile ezilenin birbirine benzediği bir yer burası... Neden mahkûm edildik anlayamadım. Bir de hürriyete kavuştuk ki, ne görelim? Bir birlik, bir beraberlik, bir dayanışma, bir kardeşlik! Hiç şaşmadık. Neden şaşmadık. Herkes birbirine benziyordu zaten eskiden beri... ${ }^{10}$

Savundukları düşünceler dolayısıyla mahkûm edilip 12 Eylül'ün gerçek yüzüyle tanıştıklarında yalnız bırakılmaları ve eskiden özgür olduklarında savundukları ile karşı çıktıklarının şimdi aslında aralarında bir fark olmadığına tanıklık etmeleri onları hem kendilerine hem içinde yaşadıkları zamana hem de topluma yabancılaştırmıştır. Farklılıkları ortadan kaldıran, bir anlamda sivrilikleri törpüleyen 12 Eylül'e herkes kendini teslim ederek yaşanan zulme sessiz kalmıştır. Ne halk, ne de emirlerin uygulayıcıları kendilerini 12 Eylül'ün yaptığı zulümden sorumlu tutmamıştır. Onların şimdiki yabancılıklarının en büyük sorumlusu bu zulüm karşısında suskunluğuyla bunu onaylayan toplumdur. "Bir de hürriyete kavuştuk ki, ne görelim? Bir birlik, bir beraberlik, bir dayanışma, bir kardeşlik!" "li Şimdi birbirine benzeyen bu insanların yaşama hakkını savunmak için eskiden verdikleri mücadele boşa düşmüştür. Hapisten çıktıklarında toplumsal gerçeklik çoktan yeni düzenin isteklerine göre değişmiştir bile. Geriye baktıklarında onlara şimdiyi hatırlatacak kimse kalmamıştır. Tarık'ın, "Hiç şaşmadık. Neden şaşmadık. Herkes birbirine benziyordu zaten eskiden beri"'12 sözleri de 12 Eylül öncesinde toplumsal gerçekliği üreten kitlelerin, iktidarın ya da muhalefetin, ezen ya da ezilenin, onları yok eden ya da disipline edenlerin normal insan olmasına yapılan bir vurgudur. Normal ve sorumluluktan muaf olmakla birbirine benzeyen herkes. Ayrıca Tarık'1n, 12 Eylül'ün uygulayıcılarının kendilerine benzediklerini söylemesi bir yerde normal ve sıradan insanların şeyleşmiş bilincin etkisiyle bencil ve zalim insanlara dönüşebileceğinin bir ifadesidir. Dolayısıyla aydın kesim ya da kendisini şiddetten muaf gören sıradan vatandaş, 12 Eylül'ün uyguladığı baskı ve şiddeti, kendisini bunun dışında tutarak, edilgenleşerek, ondan kaçarak, ona yabancılaşarak, bilincini şeyleştirerek normalleştirmiştir. Kendisi hedef olmamak için hem geçmişini inkâr etmek zorunda kalmış hem de uygulanan şiddeti meşrulaştırmıştır.

10 Baydur, Tiyatro Oyunlarl Sevgi Ayaklart, 564.

11 A.g.e., 564.

12 A.g.e., 564. 
Erkekler kim olduklarını anlattıktan sonra kadınlar daha fazlasına gerek duymadan konuyu dağıtmaya çalışır. Onlar 12 Eylül zulmünü yaşarken kadınlar belki yaş olarak küçükmüş ama en azından şimdi onların acılarını kanatmayacak kadar olgunlaşmışlardır. Bu akşam yabancı bir evde kadınların bu iki erkekle bir araya gelmeleri onları toplumdaki bilindik rollerine hapsetmez, bilakis onları önceki konumlarından özgürleştirir. Kendi iradeleriyle geldikleri bu evde ayakları yere sağlam basar hiç olmazsa. Erkekler zampara olamamışsa onlar da orospu olmamıştır. Toplumsal gerçeklikleri “insanların kendi özneler-arası deneyimlerinden hareketle kendilerinin inşa ettiğini" ${ }^{13}$ düşünen Alfred Schutz'a göre bu bilindik roller günlük yaşamdaki "tipleştirmeler"dir ve onların sayesinde günlük yaşam kavranarak toplumsal gerçeklik oluşturulur. ${ }^{14}$ Dul kadın tipi, zampara erkek tipi, aydın tipi, orospu tipi vs. gibi. Yazarsa toplumun kanıksadığı bu rolleri sorgulayarak gerçeklik zeminiyle oynar. Mesela Ayla'nın bir kız çocuğuna sahip olduğunu ve yedi yıl evvel kocasını kaybettiğini söylemesi toplumda tek başına, bir erkeğe yaslanmadan ayakta kalmanın ve çocuk büyütmenin mümkün olduğuna yapılan bir göndermedir. Ayla bulunduğu toplumsal konumun kodlarını taşımayarak, kendi hayat mücadelesi içinde, hayalleriyle, arzularıyla ve kendi kimliğiyle var olmaya çalışarak kanıksanmış gerçekliğin dışına çıkar.

Ayla kendi hikâyesini kısa kestikten sonra Tarık'tan, biraz önce hapiste tanıştıklarını söylediği Buldozer Osman'ın aşk hikâyesini anlatmalarını ister. Bu hikâyede Osman, Ayşe 'yi istemeye gittiği gece evden kovulunca gece Ayşe'nin mahallesini dozeriyle alt üst etmiştir, bundan dolayı da tutuklanmıştır. Nitekim tozu dumana katan bu aşk hikâyesi gelir, 12 Eylül'ün kimleri hedef aldığıyla sonlanır. Unutulsa da, anlam üretmese de, dönüşse de, geçmiş sürekli rahatsız edicidir.

TUĞRUL-On sekiz ay hapse mahkûm oldu Osman. Bir yıl yattı çıtı.

TARIK- Hemen büyük bir inşaatta buldozer ustası olarak iş buldu.

TUĞGUL-Türkiye'de çalışan her insan, şu veya bu şekilde eskiden hapse girip çıktığ için, üstelik işçi iseniz... Kimse sicil sormuyor. ${ }^{15}$

Bu cümleler 12 Eylül'ün kimleri hedef aldığının bir göstergesidir. 12 Eylül'ün hemen öncesi hükümetin imzaladığı serbest piyasa ekonomisine geçiş paketi olarak bilinen 24 Ocak Kararlarının mevcut işçi sınıfı ve sendikaların varlığında uygulanabilmesi mümkün olmamıştır. Nitekim 12 Eylül darbesinin hemen ardından "ülkemizin ekonomik durumunu düzenlemek ve daya iyiye götürmek maksadlyla yürürlüğe konulan ekonomik program ile yapılan anlaşmaların ve protokollerin uygulanmasına devam edilecektir" ${ }^{16}$ şeklinde yapılan açıklama darbenin

13 Alfred Schutz, Fenomenolojik İlişkiler, çev. Adnan Akan-Seyda Kesikoğlu (Ankara:Heretik Yayınları, 2018), 57.

14 A.g.e., $135-136$

15 Baydur, Tiyatro Oyunlarl Sevgi Ayaklarl, 568.

16 Mehmet Semih Gemalmaz, "12 Eylül Rejimi”, Yüzyll Biterken: Cumhuriyet Dönemi Türkiye Ansiklopedisi 14 (İstanbul: İletişim Yayınları, 1996), 975. 
kimlerle işbirliği içerisinde yapıldığına dair ipucu verir. Bu bağlamda Nurdan Gürbilek darbenin kimlerle işbirliği halinde ve kime karşı yapıldığını şöyle ifade eder:

Toplumsal muhalefetin başka türlü bastırllamadı̆̆ı, işçi sendikalarını başka türlü etkisizleştirilemediği, Türkiye tarihinde görülmedik ölçüde kitleselleşen sol muhalefet başka türlü susturulamadı̆̆ , her türlü yasal ve yasadışı muhalefetten arındırılmış bir toplumsal sahnede "ekonomik istikrar" başka türlü sağlanamadı̆̆ için ve kapitalizmin ekonomik-siyasi tıkanmışlı̆̆ olağan yöntemlerle giderilemediği için darbe gerçekleştirilmiştir. ${ }^{17}$

Yazar işçiler üzerinden şu anda çalışan herkesin geçmişinde bir disipline edilme ya da fişlenme hikâyesi olduğunu söylemeye çalışır. Çalışan hiç kimse öyle ya da böyle iktidarın gözünden kaçamamıştır. Darbe öncesinde ya da darbe sırasında eğer işçi iseniz kesin hapse girmişsinizdir yok eğer girmediyseniz zaten fişlenmişsinizdir. Dolayısıyla kişinin sicilinin ne olduğu çok önemli değildir, bozuk sicil, fişlenme, gözaltı, işkence, tutukluluk darbenin normalleştirdiği uygulamalardır.

Kadınların Buldozer Osman'ın hikayesinde Ayşe'nin sonunun ne olduğuna dair “Bir mimarla mı evlendi?... Ruhi bunalım mı geçirdi, Avrupalara mı gitti, saçlarını mı boyattı?... Intihar mı etti, sınıf mı atladı, belleğini mi yitirdi ${ }^{18}$ gibi çeşitli sonlar üretmesi, mevcut toplumsal gerçeklikte yerleşmiş, kalıplaşmış kadınlık konumlarının dışına çıkmaya çalışan bu kadınların aslında kendileri için belirlenen rolleri içselleştirmelerine ve düzenin bir parçası haline gelmelerine yazarın getirdiği bir eleştiridir. Ayşe'nin sonu için gele gele akıllarına yerleşik kadınlık rolleri gelmiştir. Yazar onların maskesini düşürür. Asıllarının taklidi olmakla eleştirdikleri erkekler kadar kendileri de taklittir. Oyunda katmanlı bir gerçeklik zemini kurulmuştur ve amaç tek bir gerçeklik olmadığını göstermektir. Yazarın gerçekliği, karakterlerin gerçekliği, taklit gerçeklikler gibi. Örneğin yazar, Asiye Nasıl Kurtulur? İstanbul Tebeşir Dairesi, Fırtına, Onikinci Gece, Tehlikeli Oyunlar adlı tiyatro metinleriyle de metinlerarasılık kurarak anlamı çoğullaştırır. Bu metinler kullanıldıkları yere göre anlamsızlıklarıyla anlam üreten yapılara dönüşür. Postmodernizmle birlikte kökeninden referans alan gerçeklik imgesinin kaybolduğunu düşünen Jean Baudrillard'a göre de gerçeği sonsuz sayıda yeniden üretmek mümkündür. ${ }^{19} \mathrm{Bu}$ ifade, “dışsallaşma, nesnelleşme ve içselleştirme” şeklinde Berger ve Luckmann'ın üç uğrağını belirlediği gerçekliğin sosyal inşasından "nesnelleşme” kısmının çıkarılıp bu sürecin dışsallaşma aşamasında üretilen ama henüz başkası için tanınırlığı olmayan anlamlarla doldurulmasına denk düşer. ${ }^{20}$

Evde anlamsız eylemlerden dolayı telaşı ve gergin bir hava vardır. Kadınlar onlarla buluşmayı diğerlerinden farklı oldukları için kabul etmişlerdir ama bu erkekler yapacakları

17 Nurdan Gürbilek, Vitrinde Yaşamak (İstanbul: Metis Yayınları, 2001), 29.

18 Baydur, Tiyatro Oyunlarl Sevgi Ayaklart, 568.

19 Jean Baudrillard, Simülakrlar ve Simülasyon, çev. Oğuz Adanır (Ankara: Doğu Batı Yayınları, 2017 ), 14.

20 Berger ve Luckmann, Gerçekliğin Sosyal İnşast: Bir Bilgi Sosyolojisi İncelemesi, 92. 
zamparalığın bile farkında olmayacak kadar kendilerine yabancıdır. Mesela Şule öp beni ${ }^{21}$ deyince Tuğrul onu yanağında öper. Ayla bu anlamsızlıklardan sıkılır, bunun nedeninin belleksizlik olduğunu düşünür.

\begin{abstract}
AYLA- (Ortadaki koltuğa oturur) Bunalım sever insanların arasında bellek sahibi bir insan olmak çok zor. Bu memlekette değişen ve sürekli değişen bir TEK şey var: Hafiza. Bellek. (Ayla konuşurken ŞULE ile TARIK mutfağa giderler. ŞULE mutfakta kalır, TARIK elinde bir çiçek sulama aletiyle (!) girer. Çiçekleri sulamaya başlar. AYLA kesintisiz sürdürür konuşmasını.) Insanlar, hatalar, günahlar, hırtlıklar aynı kalıyor, bellekse değişiyor durmadan. Yaşananlar, söylenenler, yapılanlar, edilenler... Hepsi yer değiştiriyor, anlam ve önem değiştiriyor, açı değiştiriyor, bellek aynı. Hafiza peşinde yirmi bin fersah! Ĕ̆er geçmişte olup biteni, olduğu gibi anımsıyorsanız, bu ülkede başınız dertte demektir! ${ }^{22}$
\end{abstract}

Belleksizliğin nedeni memlekette -şu ana kadar olduğu gibi- egemen güçlerin çıkarına uygun olarak geçmişin sürekli değiştirilmesidir. Egemen gücün kurguladığ gerçekliklerin içselleştirilmesi için eskinin, geleneğin, belleğin silinmesi gereklidir. Yeni toplumsal gerçekliği içselleştirmek, önceki öznel gerçekliklerinden vazgeçmek, kısaca anlamın taşıııcısı olan geçmişi unutmakla mümkündür. George Orwell'in 1984 romanında dediği gibi “Geçmişi denetim altında tutan, geleceği de denetim altında tutar; şimdiyi denetim altında tutan, geçmişi de denetim altında tutar... "Gerçeklik denetimi” diyorlardı buna... "23 Tıpk1 12 Eylül iktidarının memnun olmadığı eskiyi yıkıp yerine yenisini inşa etmeye çalışması gibi. Bu manada oyundaki anlamsız konuşmalar ve tavırlar, eylemler, söz oyunları, hikâyeler, tersinlemeler belleğin anlam üretememesiyle, gerçeklik imgesini kaybetmesiyle ilgilidir. 12 Eylül öncesi ve sonrası toplumsal gerçeklikte devamlılık yoktur. Bu iki erkek eve döndüklerinde onlara eskiyi ya da kimliklerini kendilerine hatırlatacak aynalardan yoksundur. Tuhaflıklarının esas kaynağını da bu durum oluşturur. Bireyin gerektiğinde "kendisinin dışında var olan ve toplum tarafindan onanmış referans noktalarına geri gitmesi, onun hatırlamak için diğerlerine" 24 yani kolektif belleğe duyduğu ihtiyacı gösterir. Bu olmadığı durumda kişi kendi kimliğinin yabancısıdır. Dolayısıyla kimliğin belirlenmesinde toplum kurucu unsurdur. Toplum, kimliği sembolik evrenin bir parçası olarak meşrulaştırır, zira "kimlik böyle bir dünya içine yerleştirilmezse anlamsız olur." 25 Tarık ile Tuğrul'un hapishanede geçirdikleri zaman onların belleklerini kaybetmelerinin bir sebebiyse diğer sebebi de hapisten çıktıklarında karşılaştıkları toplumun onların bıraktığı toplum olmamasıdır.

Onların kimliklerine yabancılaşmasını Alfred Schutz'un, Homeros'un ünlü Ilyada destanında savaştan eve dönen Odysseus'un hikâyesini ele aldığı "Eve Dönen" adlı makalesi daha iyi örneklendirebilir. Bu hikâyede yirmi yıl aradan sonra savaşmak için ayrıldığı vatanına bir

21 Baydur, Tiyatro Oyunlarl Sevgi Ayaklarl, 571.

22 A.g.e., 573.

23 George Orwell, 1984, çev. Celal Üster (İstanbul: Can Yayınları, 2016), 59.

24 Maurice Halbwachs, Kolektif Hafiza, çev. Banu Barış, (Ankara: Heretik Yayıncılık, 2017), 46.

25 Berger ve Luckmann, Gerçekliğin Sosyal Inşası: Bir Bilgi Sosyolojisi İncelemesi, 251. 
sabah uykudayken tayfaları tarafından bırakılan Odysseus gözlerini açtığında, bulunduğu yeri tanıyamaz. Burası yirmi yıl önce bırakıp gittiği yer değildir. Kayalıklar, uçurumlar, sessiz koylar ona hiç tanıdık değildir. Odysseus doğduğu baba toprağını tanıyamamanın verdiği kederle "Vah başıma gelen! Ben neredeyim? Bir başıma burada ne yaparım?" diye haykırır. ${ }^{26}$ Odysseus'un baba toprağına geri döndüğünde orayı tanımıyor olmasından çok, o toprakların artık onu kendine de hatırlatıyor olmamasıdır haykırışlarının nedeni. Kendinin kaybolması kendini hiçleştiren bir şeydir çünkü. Başkası tarafından tanınmak aslında o kişinin kendisi olduğunun meşrulaştırılmasıdır. Kişinin kendini tanıması, olduğu kişinin başkaları tarafından tasdik edilmesi ve olduğu kişiyi içselleştirmesi, hem eylem birliğini hem de zaman-mekân birlikteliğini gerektirir. Tarık ve Tuğrul gibi hapishanede olan, evden uzun süre ayrılan kişilerin eve döndüklerinde hem kendilerine hem de evdekilere yabancı olmasının nedeni budur. Yazar oyunda zamana dair birçok gönderme yaparak, zamanlarını ve gerçekliklerini kaybetmiş bu erkeklere, örneğin Çernobil gibi döneme ait bir olayı hatırlatarak onları zamanlarına geri çağırır ve gerçeklik zemini oluşturmaya çalışır.

Ayla'nın belleksiz olmakla eleştirdiği bu erkekler kadar kendi de belleksizdir. Sürekli olarak kişilerin isimlerini karıştırır. 1 Mayıs'ın bayram olduğunu söyler ama 1 Mayıs artık iş günüdür, bayram değil. Hatta bir keresinde Tarık ile Tuğrul'un adını bile karıştırmıştır. Ayla, Tarık'la Tuğrul'un adını karıştırınca Tuğrul, “kimliklerin anlamı yok artık”27 der. Çünkü artık gerçek kişiler yoktur, imajları vardır. Yeni düzen kimlikleri farklılaştırmamış tam aksi herkesi birörnekleştirmiş, aynılaştırmıştır. Hâlbuki kimlik, bizim kim olduğumuzu, inançlarımızı, değerlerimizi, ihtiyaçlarımızı, rollerimizi, tercihlerimizi, bizi diğerlerinden ayıran farklılıklarımızı, onlar tarafından nasıl görüldüğümüzü tanımlamaya yarayan bir kavramdır. Temelde "belirli bir isim tarafindan tayin edilmeyi ve bu tanımlamayı kabul etmeyi, kendine biçilen rolleri içselleştirmeyi" 28 içerir. Diğerleriyle aynı olmak bir anlamda kendi olarak var olmamakla özdeştir. Kişiyi diğerlerinden ayırmayan, kendine ait bir öznelik konumu bulunmayan, adına yabancı olunan yerde herkes birbirinin aynıdır. Tuğrul'un Tarık'tan, Şule'nin Ayla'dan ya da toplumdaki herhangi birinden farkı kalmamıştır. 1980 sonrasının gerçeklikleri üreten, kimlikleri kişiye özel kılan öznelik konumları silikleşmiştir çünkü. 12 Eylül öncesi toplumsal gerçeklik üzerinde hegemonik olan muhalif kimlikler, 12 Eylül sonrasının gerçekliklerine uygun olmadığı için sistem dışına atılmıştır.

Ne erkekler bu akşamın erkeklik rollerine uygundur ne de kadınlar kadınlık rollerine. Tarık mutfağa makarna pişirmeye gitmiştir. Ayla ise ortalığı toplamak, yemek yapmak, bulaşık yıkamak, halıyı düzeltmek gibi kanıksanmış kadınlık rollerine isyan ediyordur ve bir kadın

26 Alfred Schutz, "Yabancı: Bir Sosyal Psikoloji Makalesi”, Yabancl- Bir İlişki Biçimi Olarak Ötekilik içinde, Der. Levent Ünsaldı, çev. Kübra Eren (Ankara: Heretik Yayıncılık, 2016), 53.

27 Baydur, Tiyatro Oyunlarl Sevgi Ayaklarl, 575.

28 Paul Gleason, "Kimliği Tanımlamak: Semantik Bir Tarih”, Kimlik Politikaları Tanınma, Özdeşlik, Farklılık içinde, Der. Fırat Mollaer (Ankara: Doğu Batı Yayınları, 2014), 34. 
olarak sevişmek istiyordur. Şule onun bu isteğiyle "Bu, bir milletin uyanışıdır, aynı zamanda"29 diyerek eğlenir. Bu talep bir erkekten gelmeliydi, öğrenilmiş kadınlık bunu gerektiriyordu. Üstelik erkeklerde hala ses seda yoktur. Ayla sonunda Şule’ye patlar.

AYLA- (Eliyle mutfăğ işaret eder) Adamlar. Onlar da üzüntülerini öfke sanıyorlar. (Bir an duraklar) Huzura susamış soluk şehzadeler... (İçer) iyi insanlar.! Şimdi birisi gelse bizi uygunsuz vaziyette yakalayacak! Biz burada oturduk söyleşip içiyoruz. Adamın biri mutfakta makarna pişiriyor, öbürü banyoda ylkanıyor. Bundan daha uygunsuz vaziyet olur mu? Valla bu ülkede herkes keçileri kaçırmış, memleketin Ísviçre'ye tedavi için gönderilmesi icap ediyor. Ancak oradaki doktorlar anlar... ${ }^{30}$

Bulundukları durumun saçmalığını anlatmaya çalışır. Norm dışı, toplumun genel kabulüne aykırı eylemler söz konusudur. Kanıksanan gerçeklikler yerle bir olmuştur. Ne demek bir erkeğin mutfakta makarna pişirmesi, hem de evde yatağa atacak bir kadın varken! Saçmalık gibi görülen bu davranışların nedeni aslında insanı kuran nesnel gerçeklik zemininin yerinden oynatılmasıdır. Berger ve Luckmann'ın dediği gibi “Toplum, insani bir üründür. Toplum, sosyal bir gerçekliktir. Insan, sosyal bir üründür." 31 İnsanın dışsallaşması esnasında ürettiği gerçeklikler nesnelleşerek insandan bağımsız üretilmiş, genel kabulmüş gibi geri döner ve insanın öznel gerçekliğini oluşturur. Bu diyalektik süreç bozulduğu için diğer davranışlar gibi Tarık’ın makarna pişirmek için mutfağa gitmesi saçmalaşmıştır.

Yazarın ot yemekleri ya da krep süzet flambe ala şerburg gibi özenti oldukları çok belli olan yemekleri, ayak fetişistliği, cinsellik, spor, caz müziği gibi tüketim kültürüyle gelen ithal gerçeklikleri gündeme getirmesi yeni gerçekliğin neyin üzerine inşa edildiğini göstermek içindir. Tüketmek için neye ihtiyacı olduğuna karar veren toplum değildir, bu noktada reklam dünyası devreye girerek hangi ürünlerin tüketilmesi gerektiğini ve bu ürünleri tüketerek neye sahip olunacağını göstermiştir. 1980'li yıllarda "toplumun sesinin bile bir imaj” olduğunu düşünen Can Kozanoğlu’na göre, toplum imaj bombardımanı altındadır; çünkü dönem "cilalı imaj devri"dir. ${ }^{32}$

Sonuçta tepeden imajlar yağarken, gerçekle imajın birbirine karıştığı yıllar yaşandı. Değişim gerçek, ilan edilen sonuçlar birer imaj... Aş̧ın, refahın, liderlerin, zaferlerin, her şeyin ama her şeyin imajı üretildi, tüketime sunuldu... ${ }^{33}$

İmajların gerçeğin yerine geçerek yoksunluğu gidermesi ve gerçeğine gerek kalmadan tatmin sağlamasıyla her alanda üretilen imaj kimlikler tüketime sunulmuştur. Yine Şule'nin "bir milletin uyanışı" ${ }^{34}$ diyerek dalga geçtiği şey dönemin imaj kimliklerine ve değişen

29 Baydur, Tiyatro Oyunlarl Sevgi Ayaklarl, 576.

30 A.g.e., 575.

31 Berger ve Luckmann, Gerçekliğin Sosyal İnşast: Bir Bilgi Sosyolojisi İncelemesi, 92.

32 Can Kozanoğlu, Cilalı İmaj Devri (İstanbul: İletişim Yayınları, 1992), 8.

33 A.g.e., 8.

34 Baydur, Tiyatro Oyunlarl Sevgi Ayaklarl, 577. 
gerçekliklerine yapılan bir göndermedir. Örneğin yazar evde bir butiğin adının yazılı olduğu torbayı göstererek reklam dünyasının eve nasıl girdiğine dikkat çekmiştir. Bu bağlamda 12 Eylül'ün toplumu baskı aygıtlarıyla disipline etmesinin yanında yeni düzeni serbest piyasa ekonomisinin ihtiyaçlarına göre, kullan at mantığına göre, tüketim kültürüne göre, kısa süreli belleğe göre kurguladığ 1 görülmüştür. Yazara göre, gerçekliğin değiştirilmesi sıradan bir konu değildir, bunun arkasında toplumun gerçek problemlerini gözden kaçırmaya çalışan baskı aygıtlarına ve maddi güce sahip olan sınıfların çıkarları vardır.

Şiddet ve baskıyla öznel gerçeklikleri tahrip olmuş erkekler kadınlar tarafından saçma bulunur, çünkü onlar kadınların daha önceden öğrendikleri ve içselleştirmiş oldukları erkeklik rollerine ters düşmüştür. Şimdi onlarla çoktan yatağa girmiş olmalıydılar. Ger gör ki eve dönen bu yabancılar her şeyi unutmuştur. Zaman kavramları parçalanmış, eylemleri saçmalaşmış, bir türlü kendilerine verilen role girememişlerdir. Mademki kadınlar bu adamlarla sevişemeyecekler o zaman buradan gitmeliydiler. Ama bir taraftan da onları bir türlü bırakıp gitmeye gönülleri varmaz. Bu yabancı erkeklerde kadınların unuttuğu bir naiflik, duygusallık ve şaşkınlık hali vardır. Gidip gitmeme arasında bocaladıkları sırada duştan çıkmış ve pembe bornoz giyinmiş Tuğrul gelip Ayla'nın yanına oturur. Tarık da elinde tabaklarla mutfaktan gelir. "Makarnalar hazır!" ${ }^{35}$ Peki bu yabancılar nasıl evcilleşecektir?

\section{Tanığı Öldürülenler}

İkinci perde açıldığında geceyi geçirdikleri seyahatteki Cemal Bey’in evi darmadağınıktır. Yerle bir olmayan hiçbir şey yoktur odada. Her şey her yerdedir. Küllükler, bardaklar, tabaklar, kıyafetler... Salonun ortasında yorganın altından ilk olarak Tuğrul çıkar ve şaşkınlık içinde etrafa bakarak üstüne bir şeyler geçirir. Tarık da uyanmıştır, onun da başında bir kadın iç çamaşırı vardır. Gece kim olduklarını hatırlamaları için bayağı çabanın sarf edildiği bellidir. Durumları şaşkındır ama hallerinden memnun gözükürler. Tuğrul yerde durduğunu fark etmediği bir düdüğe basar. Düdüğün orada ne işi vardır? Düdüğün olduğu yerde bir suç işlenmiştir demek ki. Tuğrul onu yerden alır ve öttürür. Bu düdük, 12 Eylül’ün bireyin içine yerleştirdiği denetleme aygit1 "panopticon" ${ }^{36} \mathrm{u}$ temsil eder.

35 A.g.e., 578.

36 "Panopticon, İngiliz Filozof Jeremy Bentham tarafindan 1785 yılında tasarlanan bir hapishane modelidir. Mahkumların merkezi gözetleme kulesi tarafından ne zaman gözetlenip gözetlenmediğini bilemeyecekleri tarzda tasarlanmıştır. Halka biçimli bir binadır, ortasında bir avlu ve avlunun ortasında bir kule vardır. Halka hem içeriye hem dışarıya bakan hücrelere bölünmüştür. Bu küçük hücrelerin her birinde, kurumun hedefine uygun olarak, yazı yazmayı öğrenen bir çocuk, çalışan bir işçi, ıslah edilen bir mahkum, deliliği yaşayan bir deli vardır. Merkezi kulede bir gözetmen vardır. Her hücre hem içeriye hem de dışarıya baktığından gözetmenin bakışı tüm hücreyi kat edebilir; hiçbir karanlık nokta yoktur ve sonuç olarak, bireyin yaptı̆̆ 1 her şey bir gözetmenin bakışına açıktır; bu gözetmen kendisinin her şeyi görebileceği, buna karşılık kimsenin kendisini göremeyeceği şekilde panjurlar, yarı açık bölme pencereleri arasından gözlemde bulunur. Bentham' a göre, bu küçük ve harikulade mimari kurnazlığı bir dizi kurum kullanabilir. Panopticon, aslında, bir toplum ve bir iktidar türünün ütopyasıdır." Bkz. Michel Foucault, "Büyük Kapatılma”, Seçme Yazılar, çev. Ferda Keskin (İstanbul: Ayrıntı Yayınları, 2011), 224. 
12 Eylül bireyi sadece baskı ve şiddet yoluyla disipline etmemiş zihnini de denetim altına almıştır. Bu şekilde disipline etme biçimi Michel Foucault'un "disiplinci iktidar" tanımına benzer; bu iktidar biçimi "farklılaştırarak, klyaslayarak, hiyerarşik hale getirerek, dışlayarak ve türdeşleştirerek özneyi tek kelimeyle normalleştirir". ${ }^{37}$ Bu iktidarın amac1, "normalleşmeyi" sağlamaktır; yani her türlü "toplumsal ve psikolojik bozuklukları ayıklayarak hem zihni hem bedeni uysallaşmış, kolayca öğrenen özneler yetiştirmektir." ${ }^{38}$ Bütün siyaset ve toplum kanallarının depolitize edildiği bu süreçte özellikle basın-yayın ve medya sektörü gerçekliği iktidarın lehine yeniden inşa etmesi için denetim altına alınmıştır. Örneğin gazetelerin ya da dergilerin ne yazıp ne yazamayacağı darbeci subaylar tarafından sürekli denetlenmiş ve darbe düzeninin çıkarlarına uygun şekilde yayın yapmaları sağlanmıştır. Televizyon ve radyo konuşmalarına, gazete sütunlarına, ders kitaplarına, kurumlara, tüm siyasal, ekonomik ve kültürel alanlara yapılan müdahalelerle normal ve anormal olan, makbul ve sakıncalı olan, iyi ve kötü olan, yerli ve diş mihrak olan v.s. belirlenerek toplumsal normlar oluşturulmuştur. Bunun sonucu olarak da toplum tıpkı panopticon aygıtı gibi kendi polisini içine yerleştirerek kendini sürekli gözetlemiş ve düzenin normlarına göre kendini disipline etmiştir. Darbe düzeninin hakikatlerini kendi hakikatleri gibi içselleştiren özneler, düzenin normlarıyla kendi bedenlerini ve zihinlerini denetleyerek öznelik konumlarını oluşturmuştur. Başka deyişle egemen güçlerin hegemonik olduğu gerçeklikleri zihninde yeniden üreterek onların boyunduruğu altına girmiştir. Böylece 1980 döneminin Tarık ve Tuğrul gibi özellikle şiddetle uysallaştırılan bireyleri, yaşadığı anın zihnini belirlemesiyle an'a takılı kalmış, yeni normlarla onu belirleyen geçmişine yabancılaşmış ve disipline edilen uysal kimliklerini içselleştirmiştir.

Tuğrul yaşadığı bu gecede bir terslik olduğunu fark etmiştir; tuhaflıklarının nedenini anlamıştır sanki, dili çözülmüştür. "Hayatı tepe taslak yaşattılar bize bu adamlar"39 der. Geçmiş bir hesaplaşma nesnesi olarak önlerindedir artık. Hayatta bir denge vardır ve her şey sırasıyla yaşanmalıdır. Okula gidilmeli, şiirler, şarkılar ezberlenmeli, kızlarla gezilmeli, akordeon eşliğinde danslar edilmeli, müzelere, sergilere gidilmeli, imtihanlara girilmeli... Yaşamadıklarını ama yaşamaları gerekenleri sıralar.

TUĞRUL- Üniversitede hayat ile bağları kopmamalıydı insanların. Acayip insanların rol modeli diye sunulduğu yer değil, bir bilim ve coşku kaynă̆ı olmalıydı üniversite. Canlı ve rengarenk bir tartışma ortamı içinde unutulmaz dostlukların, dayanışmaların, aşkların ve keyifli çekişmelerin yaşandiğı bir hayat dilimi olmalıydı üniversite... Orada olgun insanlar olarak hayatımızın çerçevesini çizmeliydik. Sonra ... Asıl zorlu yıllar başlamalıydı. ${ }^{40}$

Hayatları böyle olmamıştı. Üniversitedeyken hatta lisedeyken daha iyi bir dünya için savaş vermişler, devrim yapmaya girişmişler, egemen güçlerle mücadele etmişlerdi. Ülkenin siyasal

37 Michel Foucault, Hapishanenin Doğuşu, çev. Mehmet Alı Kılıçbay (Ankara: İmge Yayınları, 1992), 230.

38 Gencay Şaylan, Postmodernizm (İstanbul: İmge Yayınevi, 2002), 261.

39 Baydur, Tiyatro Oyunlarl Sevgi Ayaklart, 585.

40 A.g.e., 586. 
aktörleri yapılması gerekenleri yapmadığından, ellerini taşın altına koymadığından, dahası yangına körükle gittiklerinden her gün onlarca genç katledilmişti. ${ }^{41}$ Üniversite hocaları bile katledilenler arasındaydı. Özellikle üniversiteler 1980 öncesinin anarşi ortamının sorumlusu ilan edilmişti. Üniversiteler çeşitli gruplar tarafinda işgal edilmişti, gerçekten de bu şiddet ortamında bilim yapmanın imkânı kalmamıştı. Tarık ve Tuğrul mücadeleyle dolu gençliklerini şöyle anlatır:

TARIK: Biz hiç oynamadık. Hiç öpüşmedik gençliğimizde. Hiç pastaneye, plaja, dansa gitmedik. Hep sırtımıza ve beynimize yüklenen bir öfkenin altında yaşadık. Ben... On altı yaşındayken devrimci olduğumu söylüyordum.

TUĞRUL: Sonra... Ülkeyi düzeltmeye giriştik. Yarımı öldü, öldürüldü... Öbür yarımız hapishaneyi tanidl...

TARIK: Insan ihtiyarliyor. Yani bu duruma, devrimci olarak bile karşı koyamıyorsunuz.

TUĞRUL: En iyi yıllarımızı yaşıyoruz şimdi. Bir aydın, bir iş̧̧i, bir çalışan olarak en verimli olabileceğimiz yıllar.

TARIK: Oysa barlardan, diskoteklerden çıkmıyoruz şimdi de. Kadınları, seksi, sevişmeyi, serseriliği, başı bulutlarda gezmeyi, duygulanmayı ve saçmalamayı keşfettik kıçımızda kıllar ağarırken!

TUĞGUL: Yirmi yaşında yapamadĭ̆ımızı şimdi yaşamaya çalışıyoruz.

TARIK: O yıllardaysa, şimdi yapmamız gerekenleri yüzümüze gözümüze bulaştırıyorduk! ${ }^{42}$

Şimdi geldikleri kırk yaşlarında yapmaya çalıştıkları ve ellerine yüzlerine bulaştırdıkları şey, o yıllarda yapmaları gereken ama memleket derdinden firsat kalmadığı için yapamadıkları şeydir. Normalde üniversiteye gitmiş, askerliğini yapmış, evlenmiş, belli ideolojiler benimsemiş, hayatta belli şeyleri aşmış bir aydın, bir işçi, bir çalışan olarak bu mücadeleyi vermeleri gerekiyordu. Onlarsa hayatı tersten yaşamışlardı, yabancılıkları biraz da bundandı. Ayrıca yazarın ironik anlatımı sonucunda ülkede ne Tuğrul'un hayal ettiği gibi bir üniversite hayatının olduğunu ne de orta yaşa gelmiş bir aydının ülkesi için sorumluluk alan konumunun olduğunu görürüz. Zaten iyi bir hayat dün de bugün de hiçbir zaman olmamıştır.

Tarık ile Tuğrul'un hapiste yaşadıkları şiddet, onları öznelik konumlarından ve anlam üreten dillerinden kovarak anlamsızlaştırmıştır. Bu manada 12 Eylül'ün şiddet uygulamalarıyla yok ettiği kimliklerin gerçeklikten kaçması ve yaşadıklarını anlatamaması, farklı bir yorumla

41 “Özellikle o dönemde "komando" diye adlandırılan ülkücü gençlik örgütünün üniversitelere yönelik kanlı saldırıları arttı. Her gün bu saldırılarda ölen ve yaralananların sayısı çoğalıyordu. Faşizm adım adım soluğunu duyuruyor, tırmanıyordu. Basının bu çatışmaları verirken kullandığı, "sağ-sol mücadelesi” betimlemesini kabul etmeyen MSP'li Adalet Bakanı İsmail Hakkı Müftüoğlu, “Türkiye’de sağ-sol çatışması mevcut değildir. Yapılan mücadele Türk devletine ve milletine musallat olan ve onu kirli emelleri uğruna yıkmaya çalışan vatan hainleriyle milletin varlığını korumaya azimli memleket severlerin mücadelesidir”' (2 Aralık 1975) diyordu. Yükselen faşist terörün ve onun mimarı ülkücü gençliğin en büyük destekçisi Başbakan Süleyman Demirel'di. Demirel'in o dönemdeki, bugün bile anımsanan konuşmalarından dikkati çekenlerini burada yinelemekte fayda vardır. "Bana sağcılar cinayet işliyor dedirtemezsiniz.” Detaylı bilgi için bkz. Tevfik Çavdar, Türkiye nin Demokrasi Tarihi (1950’den Günümüze), (Ankara: İmge Kitabevi, 2013), 243.

42 Baydur, Tiyatro Oyunlart Sevgi Ayaklarl, 586-587. 
işkence olayının tanığı öldürmeye yönelik olmasıyla da ilişkilendirilebilir. Marc Nichanian Edebiyat ve Felaket adlı eserinde Brezilyalı bir yazar olan ve aynı zamanda Güney Amerika, Şili, Arjantin diktatörlüklerindeki işkencelerin etkilerini iyi bilen İdelbar Avelar'ın "şiddet" ve "dil", "deneyim” ve "öyküleme” arasında kurduğu bağı bize şöyle özetlemiştir: "Hayatta kalmak, inkâr etmektir. "43 İşkenceci, anlatı kurma imkânına sahip olan dile zarar verir ve dil bütünlüğü bozulduktan sonra bu bütünlüğü sağlayacak yeni bir dil kalmaz. Örneğin terapi eyleminde bile anlatı kurulacak bir dil bulunmaya çalışılması ya da anlatı vaat edilmesi olayın tanığı kalmadığı içindir. Anlatmaksa ancak olaya ihanetle gerçekleşir. İşkenceye maruz kalanlar yaşamaya devam edebilmek için bunu anlatılaştırdıklarında o işkence artık yaşadıkları işkence olmaktan çıkar. Oyunda Şule'nin Tuğrul'a uzun süre banyoda ne yaptığını sorması üzerine Tuğrul'un “acının saati yoktur"44 diyerek susması bugünü anlamlandıracak bir dilinin olmamasından kaynaklanır. İşkenceyle birlikte tanıklıkları ortadan kalktığı için şimdi sanki yaşadıklarının tanıklarıymış gibi anlatmaları, tanık olmadıkları halde tanıkmış gibi yapmaları yaşadıkları olaya ihanet etmeleri demektir. Raporlar, belgeler, görsel materyaller ya da tanıkların anlattıklarının bu durumda bir önemi yoktur. Bu tanıklıklar tanıklık edildiği varsayılan olaylardır, dolayısıyla dil bütünlüğünün bozulması veya tanığı saf dışı bırakmakla ilgili bir fikir veremez. İki eski tutuklunun metin boyunca anlamsızlıklarının, zamanın dışına düşmelerinin, susmalarının, sürekli alkol almalarının, kelime oyunu oynamalarının nedeni belki de anlatarak yaşadıkları işkenceye ihanet etmek istememeleridir.

Tarık ile Tuğrul geçmiş sorgulaması yaparken bir taraftan da Ayla ve Şule’yle birlikte dağıttıkları evi toplamışlardır. Yavaş yavaş kadınların gitme zamanı gelmiştir. Bir sonraki buluşma zamanı ayarlandıktan ve kısa bir vedadan sonra kadınlar gitmiştir. Fakat bu geceden geriye tersten yaşadıkları hayatlarında, utangaç aşığa dönüşen iki erkek kalmıştır. Tuğrul'un âşık olduğu "belleksiz” Ayla'yı saygıdeğer bir aydın diye tarif etmesi, yine yazarın bir ironisi olarak 12 Eylül sonrası değişen aydın biçimine yapılan bir göndermedir. Oyunun anlatı diline ironi ve oyunsuluk hâkimdir. "Sevgi Ayakları"ndaki "ayak" kelimesi bile, gerçek olmayan, mış gibi olan, taklit olan sevgiye gönderme yapar. Tarık ile Tuğrul sanki başka bir evrene aitmiş hissi verirler, kelime oyunlarıyla bulundukları zamana tutunmaya çalışırlar. İletişime geçme çabalarıyla iletişimsizliği üretirler. Samuel Beckett'in Godot'yu Beklerken ${ }^{45}$ adlı oyunundaki Didi ve Gogo gibi, yabancısı oldukları kimliklerinde, yer ve zamanda oyunlarla ayakta durmaya çalışırlar.

$\mathrm{Bu}$ gecenin sonundaki “aşk” onlara gençliklerinde yaşayamadıkları güzel duyguları ve mücadelede kaybettikleri kimliklerini geri kazanma şansı verecektir. En azından onlar böyle düşünmektedir.

43 Marc Nichanian, Edebiyat ve Felaket, çev. Ayșe Gül Altınay (İstanbul: İletişim Yayınları, 2011), 32.

44 Baydur, Tiyatro Oyunlarl Sevgi Ayaklarl, 577.

45 Samuel Beckett, “Godot’yu Beklerken”, Toplu Oyunlarl 1, çev. Uğur Ün (İstanbul: Mitos-Boyut Yayınları, 1993). 
TUĞRUL- Hayat kapısını açacağız sonunda.

TARIK- Açacă̆ız.

TUĞRUL-Aslımızı görecekler Tarık abi. ${ }^{46}$

Bir gecelik zamparalık hikâyeleri onlara yabancılaştıkları, kaçtıkları, unuttukları, bastırdıkları geçmişleriyle yüzleşme firsatı vermiştir. Onların bellekleri de Cemal Bey'in çiçekleri gibi bol bol sulanmış, kimliklerine kavuşacakları, evcilleşecekleri kapı aralanmıştır. Zamparalık gecesinden aşkla çıkarak, gençliklerini en baştan yaşayacak olmanın ve kendilerine ayna olacak belleklerine kavuşacak olmanın heyecanını yaşarlar. Bulundukları zamanın yabancısıdır onlar. Hayat kapısını açıp 12 Eylül öncesinin asıl kimliklerine ulaşacaklarına dair umutları vardır. Fakat "Bu olay lafina deli oluyorum! Ne olayı oğlum?! Trafik kazası mı var burada? Olaymış! Televizyon Türkçesi bunlar" ${ }^{47}$ diyerek içinde bulundukları dönemi eleştirmelerine rağmen cümlelerin arasına "Very good. Nazdrovya! Öptüm canım!" "48 gibi kelimeler sıkıştırmaları kendilerinin de yeni gerçekliğin bir parçası olduğunu göstermiş̧tir. Yazara göre, 12 Eylül'ün zulmüne uğrayanların evcilleşmesi onların eve dönüşünden daha vahimdir. Onları onlar yapan öznel konumlarından, kendiliklerinden, gerçeklik evrenlerinden kovularak hiçleştirilmişlerdir ancak daha da önemlisi artık işgal ettikleri muhalif, özgür ve sorgulayan konumlarından olmadıklarına hatta karşıt olduklarına dönüşerek eve girebilmişlerdir. Mesele tam da budur; karşıtına dönüşerek eve girmek, yani evcilleşmek. Bu anlamda metnin sonu onların kaybettikleri kimliklerini bulma noktasında umut vaat etmez; çünkü buldukları kimlik onların kaybettiği kimlik değildir.

\section{Sonuç}

Son kertede 1980'li yılların toplumsal pratiğini, 12 Eylül darbecilerinin biçimlendirdiği ortak değer ve davranışların hâkimiyeti altında kurgulanan gerçekliklerin oluşturduğunu ifade ederken, bu gerçekliklerin içselleştirilip öznel gerçeklere dönüşmesi için, var olan toplumsal ilişkilerin devletin baskı ve ideolojik aygıtlarıyla beraber yeniden üretilerek toplumun denetim altına alındığını ve devlete itaat eden öznelerin yaratıldığını ifade etmek gerekir. Dolayısıyla bu oyun toplumsal gerçekliğin inşa mekanizmalarını açık ederek bu sürece hâkim olan güçlerin farklı gerçeklikleri nasıl ortadan kaldırdığını ve yeni düzenin nasıl inşa edildiğini göstermiştir. 12 Eylül'ün kayıp kimliklere dönüştürdüğü kişilerin hikâyesinin anlatıldığı bu oyunda, 12 Eylül'ün zulmüne uğramış bireylerin belleklerini kaybettikleri için kimliklerini de kaybettikleri ve bunun sonucunda hem kendilerine hem de topluma yabancılaştıklarının altı çizilmiştir. Yazar iki eski tutuklu üzerinden yeni düzenle hesaplaşırken somut olaylar kadar, bu olayları normalleştiren gerçekliğin nesnelleşme sürecini ve egemen gücün gerçekliklerini şeyleşmiş bilinçle değiştirilemez gören bireyini de bu hesaplaşmaya dâhil etmiştir. Ayrıca 12

46 Baydur, Tiyatro Oyunlarl Sevgi Ayaklarl, 595.

47 A.g.e., 594.

48 A.g.e., 596. 
Eylül'ün kurduğu yeni düzenin içselleştirilmesinde ve meşrulaştırılmasında yine 12 Eylül'ün sıradanlaştırarak ve değersizleştirerek toplumu aydınlatma konumundan vazgeçirdiği kendi ben'ine odaklanarak bireyselleşen entelektüellerin de sorumlu olduğunu göstermiştir. Geçmişin idealleştirilmeden ele alındığı bu oyunda yeni düzen eleştirisi, doğrudan kişileri ve olayları hedef almadan, yabancılaşan ve anlamsızlaşan birey davranışları üzerinden postmodern anlatı teknikleriyle birlikte dolaylı yollardan yapılmıştır.

Peer-review: Externally peer-reviewed.

Conflict of Interest: The author has no conflict of interest to declare.

Grant Support: The author declared that this study has received no financial support.

Hakem Değerlendirmesi: Dış bağımsız.

Çıkar Çatışması: Yazar çıkar çatışması bildirmemiştir.

Finansal Destek: Yazar bu çalışma için finansal destek almadığını beyan etmiştir.

\section{KAYNAKÇA / BIBLIOGRAPHY}

Baudrillard, Jean. Simülakrlar ve Simülasyon, çev. Oğuz Adanır. Ankara: Doğu Batı Yayınları, 2017.

Baydur, Memet. Tiyatro Oyunları Sevgi Ayakları. İstanbul: İletişim Yayınları, 2016.

Beckett, Samuel. “Godot’yu Beklerken”, Toplu Oyunları 1, çev: Uğur Ün. İstanbul: Mitos-Boyut Yayınları, 1933.

Belge, Murat. "Yeni İnsan Yeni Kültür", Yüzyll Biterken Cumhuriyet Ansiklopedisi 13. İstanbul: İletişim Yayınları, 1996.

Belge, Murat. 12 Yll Sonra 12 Eylül. İstanbul: Birikim Yayınları, 2000.

Berger, Peter L., Luckmann, Thomas. Gerçekliğin Sosyal İnşası: Bir Bilgi Sosyolojisi İncelemesi, çev. Vefa Saygın Öğütle. İstanbul: Paradigma Yayınları, 2008.

Buttanr1, Müzeyyen. "Cumhuriyet Devri Türk Tiyatrosunda Batı Etkisi” Turkish Studies, Language and Literature 5/2, 2010.

Çavdar, Tevfik. Türkiye'nin Demokrasi Tarihi (1950’den Günümüze). Ankara: İmge Kitabevi, 2013.

Foucault, Michel. "Büyük Kapatılma”, Seçme Yazılar, çev. Ferda Keskin. İstanbul: Ayrıntı Yayınları, 2011.

Foucault, Michel. Hapishanenin Doğuşu, çev. Mehmet Alı Kılıçbay. Ankara: İmge Yayınları, 1992.

Gemalmaz, Mehmet Semih. “12 Eylül Rejimi”, Yüzyıl Biterken: Cumhuriyet Dönemi Türkiye Ansiklopedisi 14. İstanbul: İletişim Yayınları, 1996.

Gleason, Paul. "Kimliği Tanımlamak: Semantik Bir Tarih”, Kimlik Politikaları Tanınma, Özdeşlik, Farklılık. Derleyen Fırat Mollaer. Ankara: Doğu Batı Yayınları, 2014.

Gürbilek, Nurdan. Vitrinde Yaşamak. İstanbul: Metis Yayınları, 2001.

Halbwachs, Maurice. Kolektif Hafiza, çev. Banu Barış. Ankara: Heretik Yayıncılık, 2017.

Kozanoğlu, Can. Cilalı İmaj Devri. İstanbul: İletişim Yayınları, 1992.

Nichanian, Marc. Edebiyat ve Felaket, çev. Ayşe Gül Altınay. İstanbul: İletişim Yayınları, 2011. 
Orwell, George. 1984, çev. Celal Üster. İstanbul: Can Yayınları, 2016.

Schutz, Alfred. Fenomenolojik İlişkiler, çev. Adnan Akan-Seyda Kesikoğlu. Ankara: Heretik Yayınları, 2018.

Schutz, Alfred. "Yabanc1: Bir Sosyal Psikoloji Makalesi”, Yabancı. Bir İliş̧ki Biçimi Olarak Ötekilik. Derleyen Levent Ünsaldı. Ankara: Heretik Yayıncılık, 2016.

Şaylan, Gencay. Postmodernizm. İstanbul: İmge Yayınevi, 2002.

Şener, Sevda. Gelişim Sürecinde Türk Tiyatrosu. İstanbul: Mitos-Boyut Yayınları, 2011.

Yüksel, Ayşegül. Çağdaş Türk Tiyatrosundan On Yazar. İstanbul: Mitos-Boyut Yayınları, 1997. 